\title{
DRIIIING HISTORY
}

McGee 1500-2, Humboldt County, Nevada

10 June - 23 June 79

1. OPERATOR:

2. CONTRACTOR:

3. WELI LOCATION:

4. SPUD DATE:

5. COMPLETION DATE:

6. RIG DESCRIPTION:

7. TOTAI DEPTH:
Earth Power Production Company Tulsa, Oklahoma

American Geothermal Drilling Co. Tulsa, Oklahoma

T. $45 \mathrm{~N}$, K. $27 \mathrm{E}$, Sec. 26 - NE NE Elevation: $4610^{\prime}$

10 June 79

23 June 79

Portadrill Model 524, Serial \#662, 60,000 1b. mast, $5 \frac{1}{2} \times 8$ Gardner-Denver mud pump, Atlas Copco 125 psi @ 330 CFM air compressor. 2000 ft. 2-7/8" IF arill pipe. 80 ft. $4 \frac{1}{2} "$ drill collars.

$1680^{\prime}$

Cased to 1670' with 2-3/8" tubing. 


\section{DISCLAIMER}

This report was prepared as an account of work sponsored by an agency of the United States Government. Neither the United States Government nor any agency Thereof, nor any of their employees, makes any warranty, express or implied, or assumes any legal liability or responsibility for the accuracy, completeness, or usefulness of any information, apparatus, product, or process disclosed, or represents that its use would not infringe privately owned rights. Reference herein to any specific commercial product, process, or service by trade name, trademark, manufacturer, or otherwise does not necessarily constitute or imply its endorsement, recommendation, or favoring by the United States Government or any agency thereof. The views and opinions of authors expressed herein do not necessarily state or reflect those of the United States Government or any agency thereof. 


\section{DISCLAIMER}

Portions of this document may be illegible in electronic image products. Images are produced from the best available original document. 
11 June $79 \quad 400-500$

12 June $79 \quad 0-209$

13 June 79

209

14 June 79

$209-785$

\section{SUMMARY OF OPERATIONS}

Rig up. Spud 9-7/8" hole with air at 11:15 a.m. Large cavities forming in hole. Hole won't stay clean. Set $10 \mathrm{ft}$. of 8-5/8" casing. Drill with 6-3/4" bit. Depth is $120 \mathrm{ft}$. at 2:30 p.m. Drilling with air but hole is too wet to stay clean. Mud up. Drilling is fast in interlayered sandstones. Thin air fall tuff at $110 \mathrm{ft}$. Depth is $400 \mathrm{ft}$. at midnight.

Depth is $500 \mathrm{ft}$. at $2: 30$ a.m. Trip out of hole. Rig shut down from 3:00 a.m. until noon. At noon, run $463 \mathrm{ft}$. of 2-3/8" tubing. Standby for temperature survey.

Pull 2-3/8" tubing after temperature survey. Pull 8-5/8" conductor. Ream hole with 12-1/4" bit to $209 \mathrm{ft}$. Run 202 ft. of 8-5/8" T\&C casing set at $205 \mathrm{ft}$. Cement thru casing with 72 sax Portland Type I-II cement. Plug down at 1l:00 p.m. Clean out mud pumps.

Cement $25 \mathrm{ft}$. down $(6 \mathrm{ft}$. above top casing collar). Cement with 6 sax to surface. Nipple up to 6" double manual BOP; blind rams on bottom, 2-7/8" pipe rams on top. Pressure up to 250 psi on blind rams. Pressure drops to 242 after 30 minutes. Go in hole with drill pipe. Pressure up on pipe rams to 225 psi. Pressure steady at 225 for 30 minutes. BOP test passes. Begin drilling out cement at 2:30 p.m. Top of cement a $100 \mathrm{ft}$. Drill out cement to $160^{\prime}$. Stop to pump out mud pits. Haul contaminated mud to Denio dump.

Drill cement to 209 ft. with 6" bit. Clean out mud pits once more. Mix up fresh pits. Wash to $505 \mathrm{ft}$. Hole is fairly clean. Depth is $605 \mathrm{ft}$. at noon. Depth is $780 \mathrm{ft}$. at 10:00 p.m. Bit not cutting. 


\section{DATE}

DEPTH

15 June 79

780

16 June $79 \quad 780$

17 June $79 \quad 780$

18 June $79 \quad 780$

19 June 79 780-1020

20 June 79 1020-1200

21 June $79 \quad 1200-1550$

22 June 79

$1550-1680$

23 June 79
Trip for new bit. Bearings frozen and bit worn flat. Out of 6 " bits. Re-enter hole with 6-1/4" bit. Wash to $505 \mathrm{ft}$. Ream to $780 \mathrm{ft}$. by noon. Mud pump clutch shot. Rig is down.

Rig down. Work on clutches.

Rig down.

Rig down.

Rig back in operation at 4:00 p.m. Trip into hole with 6" bit. Making mud at $900 \mathrm{ft}$. At $1020 \mathrm{ft}$. mud too thick to pump. Pump out pits.

Pump out mud pits. Mix up fresh pits. Drilling again at 4:00 a.m. Depth is 1120 at 8:00 a.m. Drawworks clutch overheated. Trip out of hole. Work on arawworks clutch. Trip into hole at 8:00 p.m. Drilling ahead at 9:00 p.m. Depth is $1200 \mathrm{ft}$. at midnight.

Drilling ahead. Intermittently hard and soft layers. Hole still making mud. Depth is 1520 at noon. Pump out pits. Mix up fresh pits.

Trip out at 1:00 a.m. for new bit. Trip in with 5-5/8" bit. On bottom at $5: 45 \mathrm{a} . \mathrm{m}$. Depth is $1680 \mathrm{ft}$. ? 10:00 a.m. Trip out of hole. Mix up fresh pit to condition hole. condition hole for 4 hours.

Trip out of hole. Haul tubing to site. Run $1670 \mathrm{ft}$. of $2-3 / 8$ " tubing. 


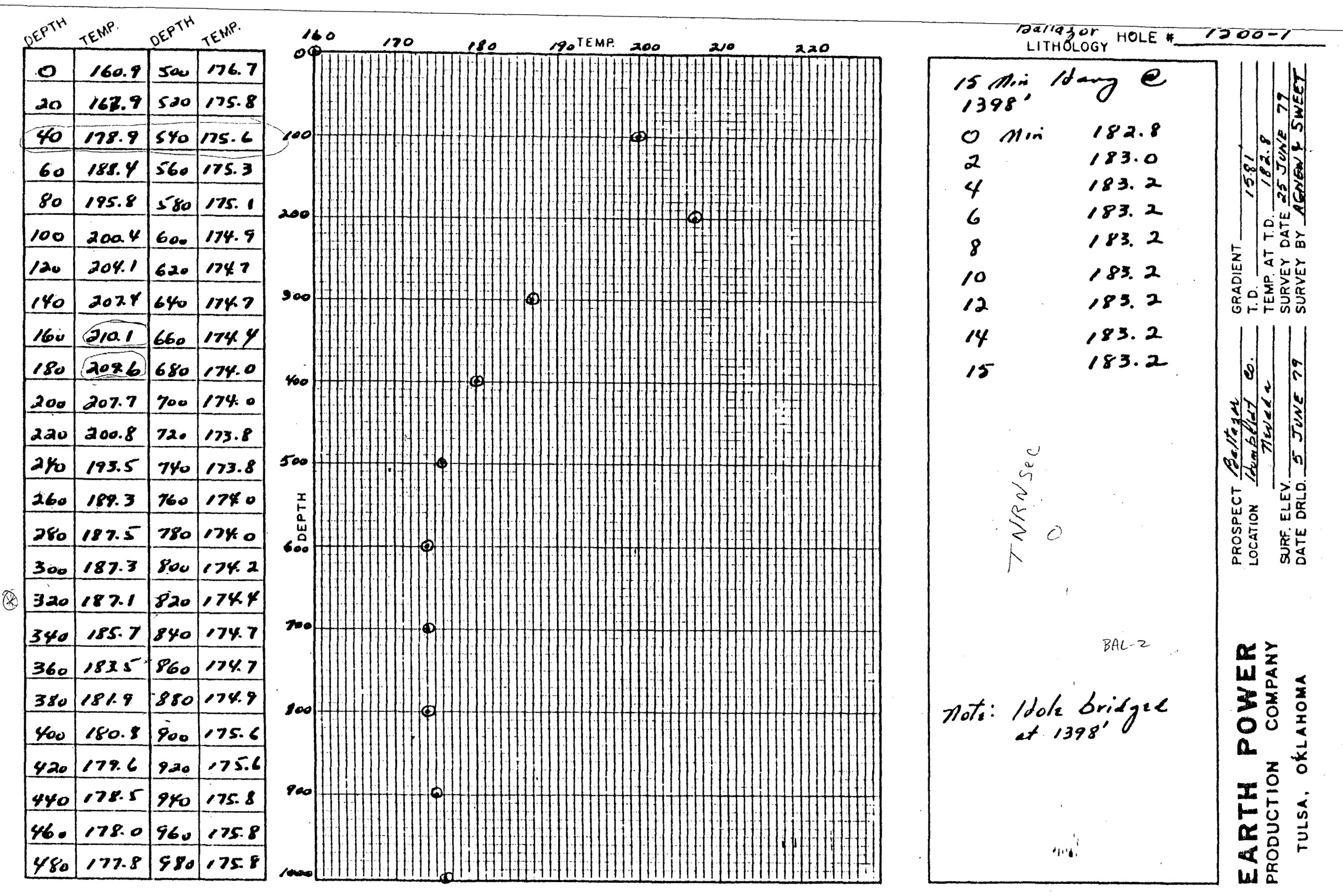


DRILLING HISTORY

Baltazor 1500-1, Humboldt County, Nevada

5 May - 5 June 79

1. OPERATOR:

2. CONTRACTOR:

3. WELL LOCATION:

4. SPUD DATE:

5. COMPLETION DATE:

6. RIG DESCRIPTION:

7. TOTAL DEPTH:
Earth Power Production Company Tulsa, Oklahoma

American Geothermal Drilling Co. Tulsa, Oklahoma

T. $46 \mathrm{~N}$, R. 28E, Sec. $14-\mathrm{NW}$ NE NW Elevation: $4218^{\prime}$

5 May 79

5 June 79

Portadrill Model 524, Serial \#662, 60,000 1b. mast, $5 \frac{1}{2} \times 8$ Gardner-Denver mud pump, Atlas Copco 125 psi a 330 CFM air compressor. 2000 ft. 2-7/8" IF drill pipe. $80 \mathrm{ft}$. $4 \frac{1}{2} "$ drill collars.

$1581^{\prime}$

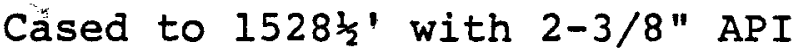
tubing. 


\section{$\underline{\text { DATE }}$ \\ DEPTH \\ 5 May $79 \quad 0-88$}

6 May $79 \quad 88-154$

7 May $79 \quad 154-154$

8 May $79 \quad 154-166$

9 May $79 \quad 166$

10 May $79 \quad 166$

\section{SUMMARY OF OPERATIONS}

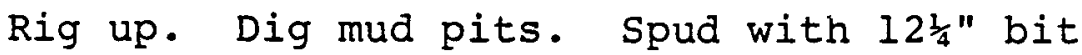
at $3: 15 \mathrm{p} . \mathrm{m}$. Drive $20 \mathrm{ft}$. 14 " casing in

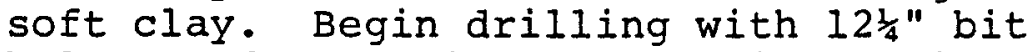
below conductor pipe. Lost circulation at 25 ft. Add cottonseed hulls and Fibertex to mud. Circulation recovered. Depth is 88 ft. at 8:00 p.m. Trip out of hole.

Trip into hole. Drilling in basaltic gravels with occasional clay layers. Return circulation good. Initial mud return temperature $=145^{\circ} \mathrm{F}$, dropping to $80^{\circ} \mathrm{F}$ as circulation continues. Lost circulation at $115 \mathrm{ft}$. Static water level drops from $3 \mathrm{ft}$. to $8 \mathrm{ft}$. below ground level. Add LCM to mud system. Circulation partially recovered. Severe lost circulation at $151 \mathrm{ft}$. Make up fresh mud pits. Pump in mud and LCM slowly. No recovery. Static water level at 5 ft. Mix up new pits. No recovery. Out of mud. Rig up to drill with foam. Trip up the hole to $40 \mathrm{ft}$. Well blows out when air is turned on. Much steam and hot water. Kill well by pumping 1500 gals. cold water.

Out of mud. Well apparently flowed overnight. Well blows out at 11:00 a.m. and dies spontaneously. Pump 3000 gals. of cold water to cool hole. Mud arrives $10: 30$ p.m.

Mix up new mud pits. Trip into hole. $15 \mathrm{ft}$. of fill up on bottom. Cannot keep hole clean because of low viscosity. Mud weight of 9 lbs./gal. or more results in lost circulation. Static water level at $8 \mathrm{ft}$. Trip out of hole at $166 \mathrm{ft}$. Decide to case to $166 \mathrm{ft}$.

Trip into hole. $3 \mathrm{ft}$. of fill up on bottom. Prepare to case... Begin running casing. Run 158 ft. of 8-5/8" T\&C, K-55 casing. Rig up to cement casing. Cement thru casing with 38 sax Portland Type I-II low alkali neat cement and water to make 440 gals. No return to surface. W.O.C.

Probe down annulus to $151 \mathrm{ft}$. with plastic pipe. No sign of cement. Come out of hole 
with plastic pipe. Drop $120 \mathrm{ft}$. of pipe. Fish out pipe. Run in annulus with iron pipe. Hole open to 149 ft. Prepare to cement. Cement thru iron pipe in annulus at 149 ft. Stage 3, 200 gal. slugs of cement. W.O.C.

Run iron pipe down annulus. Annulus bridged at $20 \mathrm{ft}$. Try to wash out bridge. Cannot break thru bridge. Pressure up on casing. Casing leaking at 100 psi. Cement 12 sax down annulus. Mix up cement to pump down annulus (25 sax cement with 3 sax hulls). Pump cement down casing. Casing comes up out of hole $2 \frac{1}{2} \mathrm{ft}$. Decide to abandon hole because of bad cement job. Move rig $15 \mathrm{ft}$. west. spud new hole with $12 \frac{1}{4} "$ bit; set $10 \mathrm{ft}$. of 14 " conductor.

12 May $79 \quad 10-130$

13 May $79 \quad 130-153$

14 May $79 \quad 153-156$

15 May $79 \quad 156$

16 May $79 \quad 156$
Mix up mud pits. Drilling with 12/4" bit. Lost circulation at $126 \mathrm{ft}$. Mix up new pits with hulls and Fibertex. Cannot recover circulation. Trip out of hole.

Mix up pits. Trip into hole. $15 \mathrm{ft}$. of fill up on bottom. slight return flow begins at $136 \mathrm{ft}$. Prepare to case at $153 \mathrm{ft}$.

Trip into hole. Hole is clean. Drill to $156 \mathrm{ft}$. to make extra hole for casing. Trip out of hole. Set 153' 6 " of 8-5/8" T\&C, K-55 casing at $155 \mathrm{ft}$. Cement baskets at 150 and $140 \mathrm{ft}$. Prepare to cement. Cement thru casing with 24 sax neat cement. Cement down annulus with 1" pipe with 26 sax. W.O.C. 6 Hrs. Cement down annulus with 24 sax. W.O.C. 8 Hrs.

Cement down annulus with 22 sax neat cement and 2 sax hulls. W.0.C. 6 Hrs. probe down annulus. Cement at $35 \mathrm{ft}$. and still soft. W.O.C. 7 Hrs. Cement down annulus with 44 sax cement and 3 sax hulls. W.O.C. 8 Hrs.

Probe down annulus. Cement at $26 \mathrm{ft}$. and hard. Cement down annulus with 20 sax cement and 2 sax hulls. Cement returns to surface, approximately 50 gals. Cement down annulus of previously abandoned hole with 12 sax. Prepare to nipple up. 


\section{DATE $\quad$ DEPTH}

16 May 79

(cont'd)

17 May $79 \quad 156-181$

18 May $79 \quad 181-261$

19 May $79 \quad 261-381$

20 May $79 \quad 381-519$

21 May $79 \quad 519-610$

22 May $79 \quad 610-721$
Wellhead as installed from casing up:

a) 900 series flange screw into 8-5/8" casing collar,

b) 9.00-600 series drilling spool 2" Iine pipe side outlets,

c) Double manual schaffer 2000-3000 B.O.P. with blind rams on bottom and 2-7/8" pipe rams on top,

d) 600 series companion flange,

e) flow nipple.

Test B.O.P. Close blind rams. Pressure up to 250 psi. Pressure drops to 221 psi after 10 minutes. Close 2-7/8" rams on drill pipe. Pressure up to 250 psi. Pressure drops to 225 after 10 minutes. Test passes.

Trip into hole. Top of cement at $110 \mathrm{ft}$. Begin drilling out cement with 6-3/4" bit. 161 ft. lost circulation. Mix up new pits with hulls and Fibertex. Trucks arrive at noon with mud, LCM, drill pipe and collars. Drilling with no returns. Trip up into casing.

Trip into hole. Drilling with no returns. Occasional 2-3 ft. cavern from 181-20l ft. Bottom of hole staying clean with 33-35 vis. Trip up into casing

Trip into hole. Hole bridged at $185 \mathrm{ft}$. Wash out bridge. No fill up on bottom. Consuming 6000 gals. hr. of mud drilling with no returns. Drilling at $25 \mathrm{ft} . / \mathrm{hr}$. at 281 ft. $320-381$ soft rock drilling at 40-60 ft./hr. Trip up into casing.

Trip into hole. Mix mud. Hole bridged at 171 and $188 \mathrm{ft}$. Drilling with no returns. Bottom of hole staying clean. Trip up into casing.

Trip into hole. Drilling with no returns. Trip out of hole.

New 6-3/4" bit. Trip into hole. Drilling with no returns. Water truck cannot keep up with lost circulation. Trip up into casing. 


\section{DATE $\quad \underline{\text { DEPTH }}$}

23 May 79 721-819 Trip into hole. Drilling with no returns. Trip out of hole with plugged bit. Trip into hole. Drilling with no returns. Trip up into casing.

24 May 79 819-881 Trip into hole. Drilling with no returns. Trip out of hole. Rig down. Build fence around drill site. Move equipment.

25 May 79

Rig in Reno for maintenance on auxiliary transmission.

4 June 79 881-1044 Rig up. Mix up new pits. Begin tripping into hole at 2:15 p.m. Hole bridged at $165,171,185$ and 240 ft. Drilling with no returns at $20 \mathrm{ft} . / \mathrm{hr}$. Static water level at $5 \mathrm{ft}$. when not drilling and at 8-9 ft. when drilling. Drilling thru interlayered hard and soft: Hard rock is $20 \mathrm{ft} . / \mathrm{hr}$. for $10-15 \mathrm{ft}$. then $3-5 \mathrm{ft}$. of $40 \mathrm{ft} . / \mathrm{hr}$. material. Trip up $60 \mathrm{ft}$. of bottom and rotate.

5 June 79 1044-1581 Drill with no returns. Trip out of hole.

Standby for logging truck. Century Geophysical truck arrives at $2: 30 \mathrm{p} . \mathrm{m}$. to run Gamma-SP-Resistivity. Hole bridged at $210 \mathrm{ft}$. Loggers probe not working. No log. Run $1528 \frac{1}{2} \mathrm{ft}$. of 2-3/8" API tubing. Wellhead consists of homemade casing hammer and 2 " $\mathrm{Hi}$ pressure ball valve on $2-3 / 8$ " tubing.

Rig down. Clean up site. 


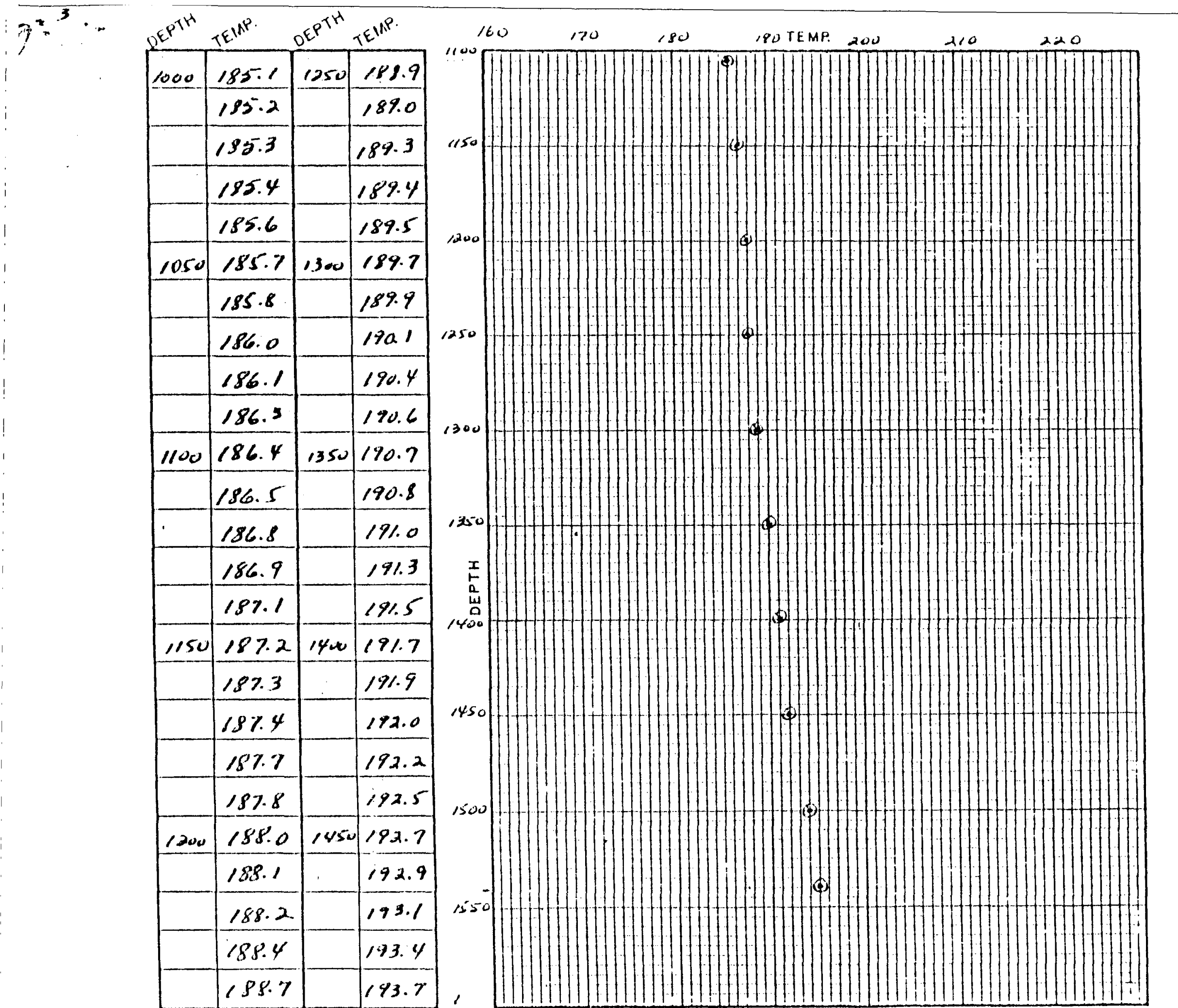

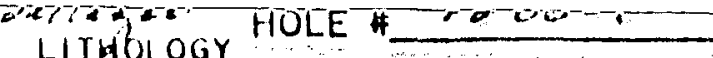

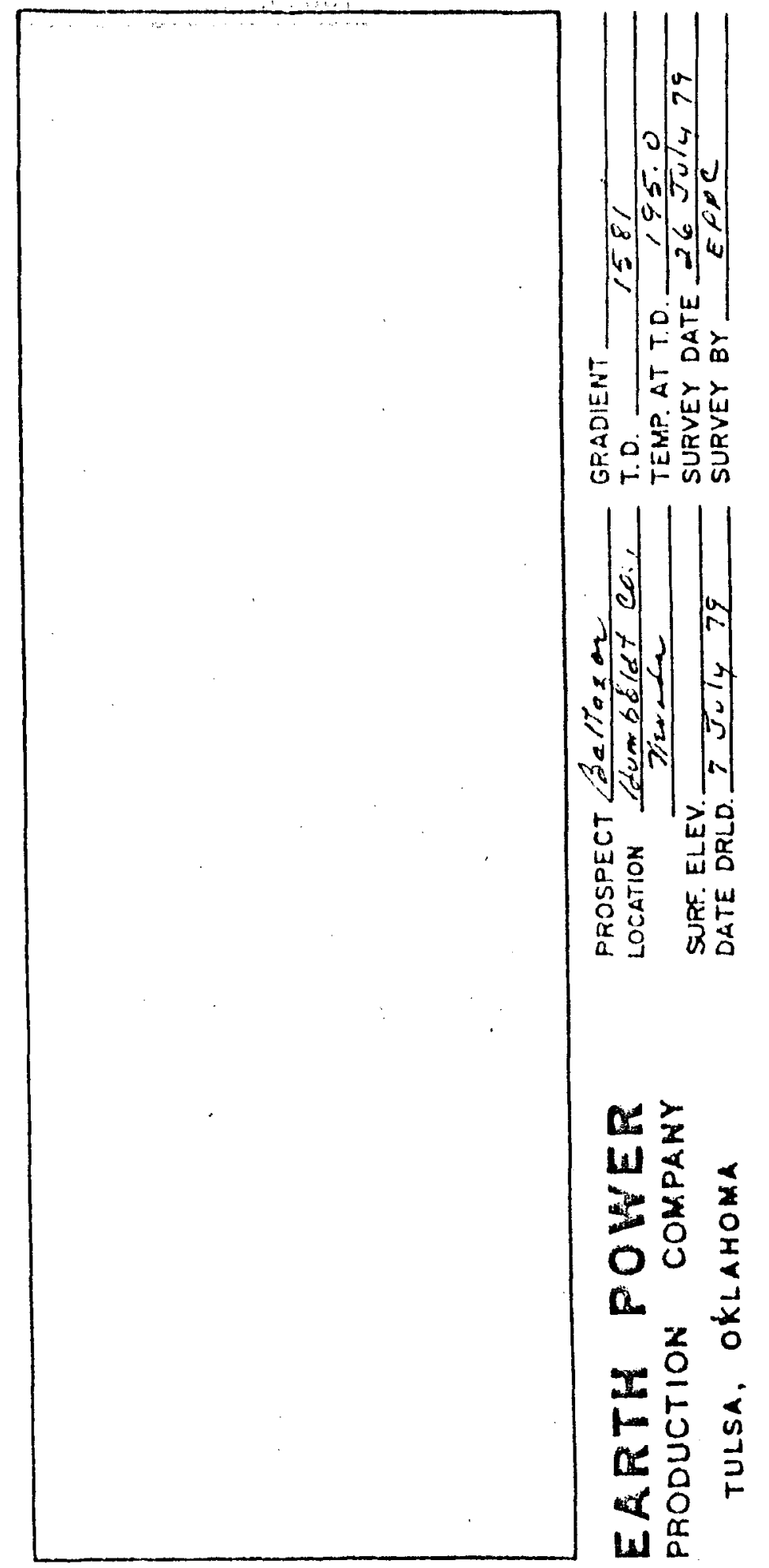


DRIIIING HISTORY

Baltazor 1500-2, Humboldt County, Nevada

28 June - 7 July 79

1. OPERATOR:

2. CONTRACTOR:

3. WELL LOCATION:

4. SPUD DATE:

5. COMPLETION DATE:

6. RIG DESCRIPTION:

7. TOTAI DEPTH:
Earth Power Production Company Tulsa, Oklahoma

American Geothermal Drilling Co. Tulsa, Oklahoma

T. $46 \mathrm{~N}, \mathrm{R} .28 \mathrm{E}$, Sec. 14 - NE SW Elevation: $4250^{\prime}$

28 June 79

7 July 79 (Added 30 ft. of tubing on 18 July 79)

Portadrill Model 524, Serial $\$ 662$,

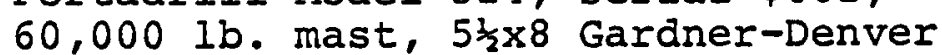
mud pump, Atlas Copco 125 psi @ 330 CFM air compressor. 2000 ft. 2-7/8"

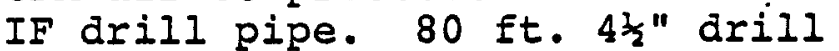
collars.

$1487^{\prime}$

Cased to 1440 with 2-3/8" tubing. 
DATE

DEPTH

28 June $79 \quad 0-40$

29 June $79 \quad 0-120$

30 June 79

$120-220$

1 July 79

$220-445$

2 July 79

$445-620$

3 July 79

$620-1000$

\section{SUMMARY OF OPERATIONS}

Set up water pipeline from Continental Lake. Repair road to site. Rig up. Mix mud. Spud at 5:30 p.m. in coarse gravels and cobbles with 6-3/4" bit.

Drilling pilot hole with 6-3/4" bit. Hole not staying clean due to large cuttings and gravel. Moderate lost circulation. Depth is $300 \mathrm{ft}$. at 7:45 p.m. Trip out of hole. Ream hole with 9-7/8" bit. Hole is reamed to $120 \mathrm{ft}$. at midnight.

Hole is reamed to $220 \mathrm{ft}$. at $1: 30 \mathrm{a} . \mathrm{m}$. Run $203 \mathrm{ft}$. of 7" T\&C casing hung at $205 \mathrm{ft}$. Cement basket at $90 \mathrm{ft}$. Cement thru casing with 56 sax portland Type I-II. Cement returns 35 Gals. to surface. Cement job done at 7:00 a.m. W.O.C. Nipple up at 5:00 p.m. to double manual B.O.P. with blind rams on bottom and $2-7 / 8$ "pipe rams on top. Haul mud. Change oil pump. At 10:15 p.m:. pressure up on pipe rams on B.O.P. to 250 psi; pressure arops to 234 after 10 Mins. Trip into hole and begin drilling out cement

Drill out cement to $210^{\prime}$ with 6 " bit. Wash to $300 \mathrm{ft}$. Encounter hard basalt at 340 . Depth is 350 at noon. Trip out for new bit. Trip in. Interlayered hard basalt and cinders. Depth is 445 at midnight.

Trip out for new bit. Trip in. Hard formation at $450 \mathrm{ft}$. Drilling faster at 475. Depth is $580 \mathrm{ft}$. at noon. Trip out for new bit. Trip in. Depth is $620^{\prime}$ at midnight.

Trip out at $620 \mathrm{ft}$. New bit. Trip in. Very hard to 710'. Intermittent hard to $820^{\prime}$. Very hard to $880^{\prime}$. Depth is 880 at noon. Depth is $970^{\prime}$ at $8: 00$ p.m. Mud return temperature is $80^{\circ} \mathrm{F}$. Depth is 1000 at 10:00 p.m. Trip out of hole. 


\section{DATE}

4 July 79

5 July 79

1000

$1000-1200$

6 July 79

$1200-1487$

7 July 79

1487

18 July 79

1487

\section{SUMMARY OF OPERATIONS}

Holiday.

Start up again at 6:00 a.m. Rebuild swivel. Trip into hole. Wash to 400. Losing circulation. Mix up new pits with LCM. Circulation recovered. On bottom at noon. Depth is $1050^{\prime}$ \& $2: 10 \mathrm{p} . \mathrm{m}$. Mud return temperature is $91^{\circ} \mathrm{F}$. Depth is 1200 ft. at midnight.

Drilling thru intermittent hard basalts $\sim 2-5$ ft. thick. Lost circulation at 1240'. Mix up new pits with ICM. Circulation recovered. Very hard formation 1355-1405 ft. Depth is $1420 \mathrm{ft}$. at noon. Depth is $1487 \mathrm{ft}$. at $4: 30 \mathrm{p.m}$. Mud return temperature is $96^{\circ} \mathrm{F}$. Mud pump breaks down. Trip out of hole.

Haul tubing to site. Run $1410 \mathrm{ft}$. of 2-3/8" tubing.

Rig down.

Add $30 \mathrm{ft}$. of 2-3/8" tubing to bring total to $1440 \mathrm{ft}$. 


\begin{tabular}{|c|c|c|c|}
\hline$e^{e^{p r t}}$ & TEMP. & of PrH $^{\gamma H}$ & TEMP. \\
\hline \multirow[t]{4}{*}{10} & 69.5 & & 98.9 \\
\hline & 70.3 & & $98^{\circ} \cdot 8$ \\
\hline & 72.1 & & 78.7 \\
\hline & 74.0 & 7 & 88.3 \\
\hline \multirow[t]{5}{*}{50} & 85.5 & 300 & $99.1=$ \\
\hline & 86.6 & & $98^{\circ} \cdot 0$ \\
\hline & 88.0 & & $9 \% .7$ \\
\hline & 90.0 & & $8 \% 4$ \\
\hline & 91.2 & - & 97.0 \\
\hline 100 & 92.6 & 350 & 96.8 \\
\hline & 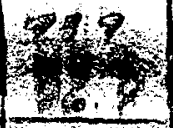 & Sta & nes \\
\hline \multirow[t]{5}{*}{150} & 92.0 & 400 & 25.2 \\
\hline & 97.4 & & 948 \\
\hline & 97.8 & & 94.9 \\
\hline & $9 \% .9$ & & 95.0 \\
\hline & 78.0 & & 95.0 \\
\hline \multirow[t]{5}{*}{200} & 28.3 & 420 & 94.3 \\
\hline & 98.5 & & 92.4 \\
\hline & 98.6 & & 91.8 \\
\hline & 98.6 & & 92.5 \\
\hline & $58-8$ & & 93.4 \\
\hline & & & \\
\hline
\end{tabular}
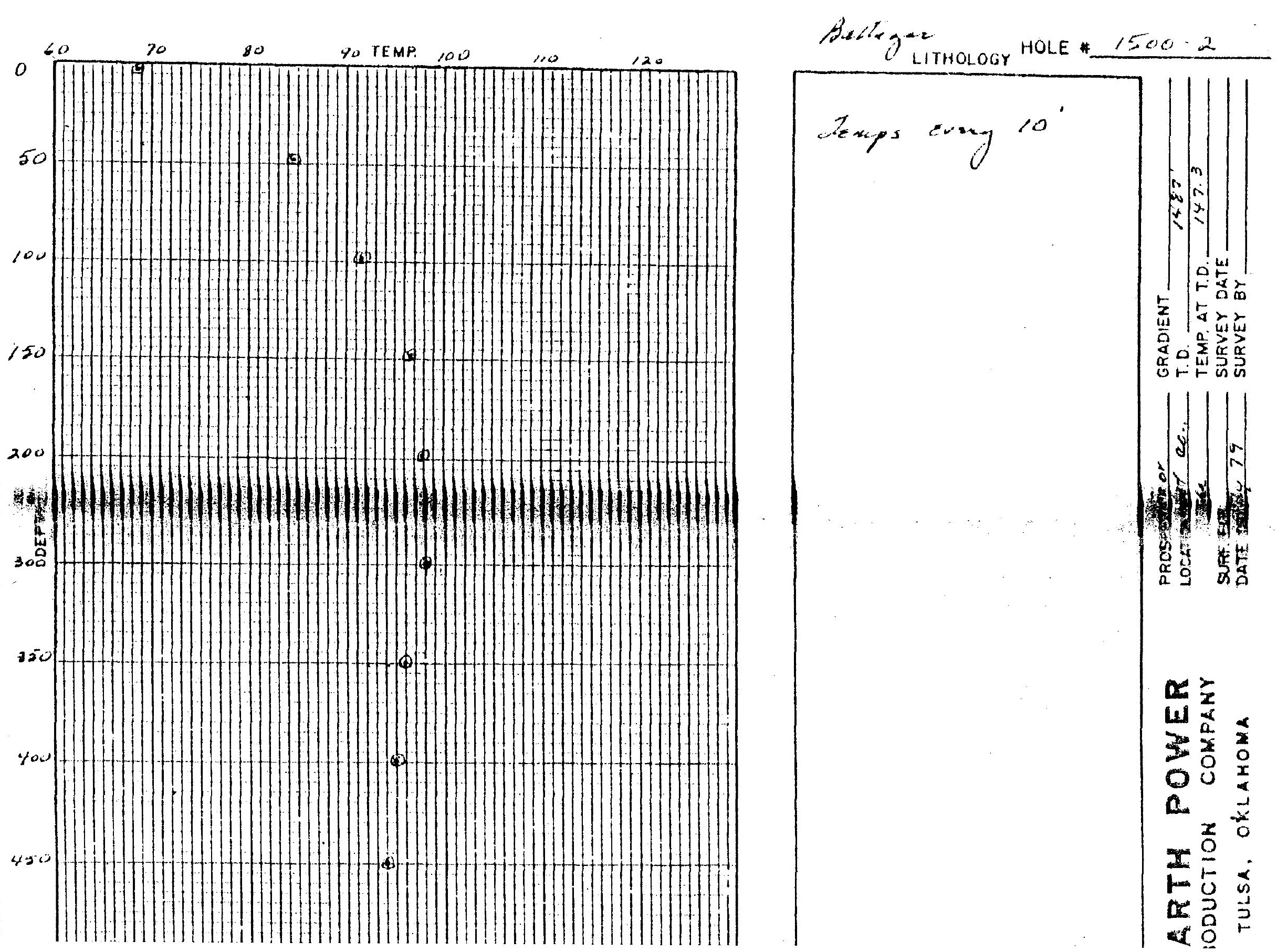


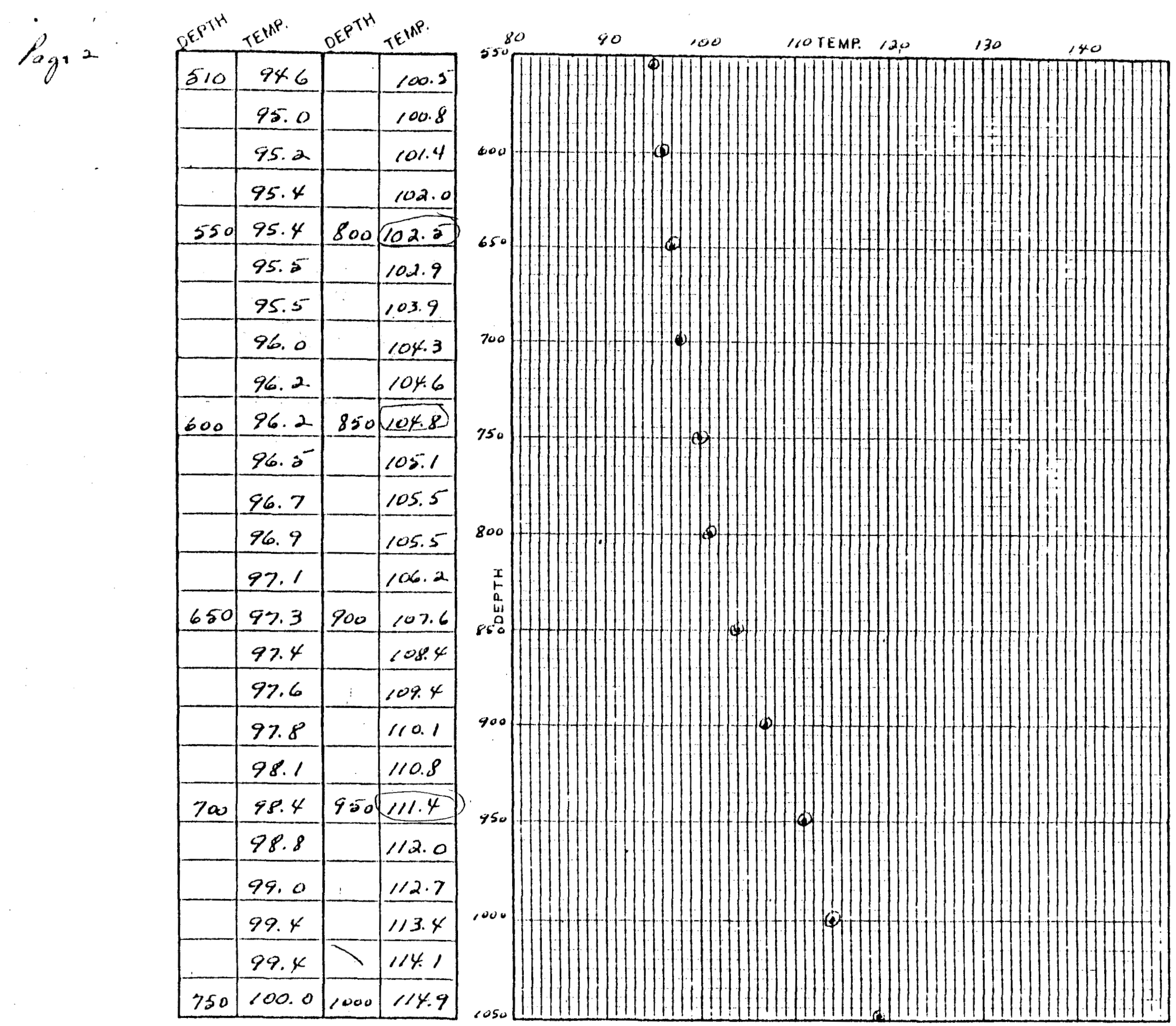

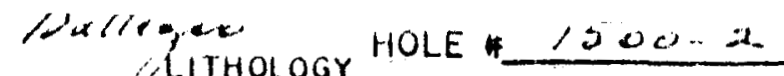

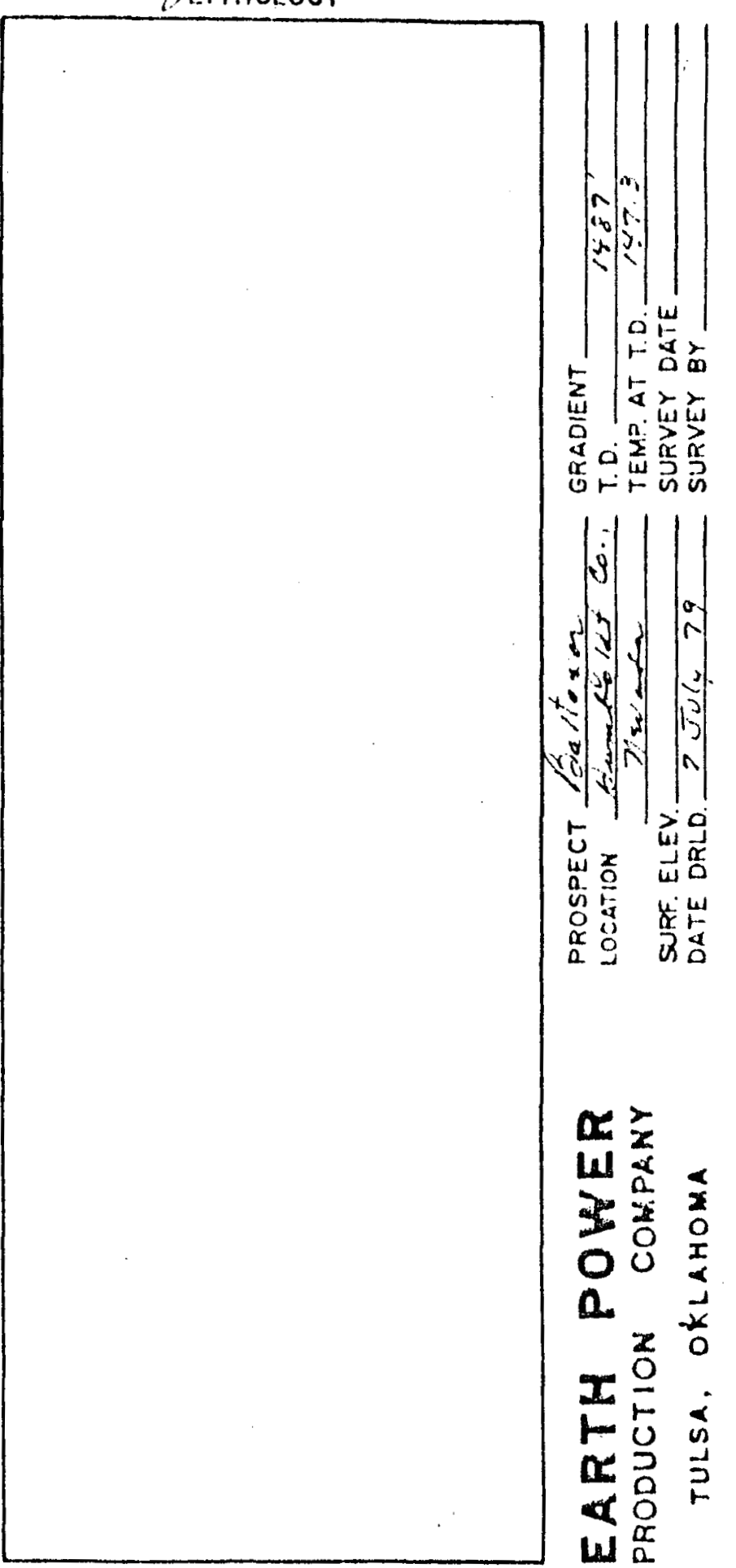




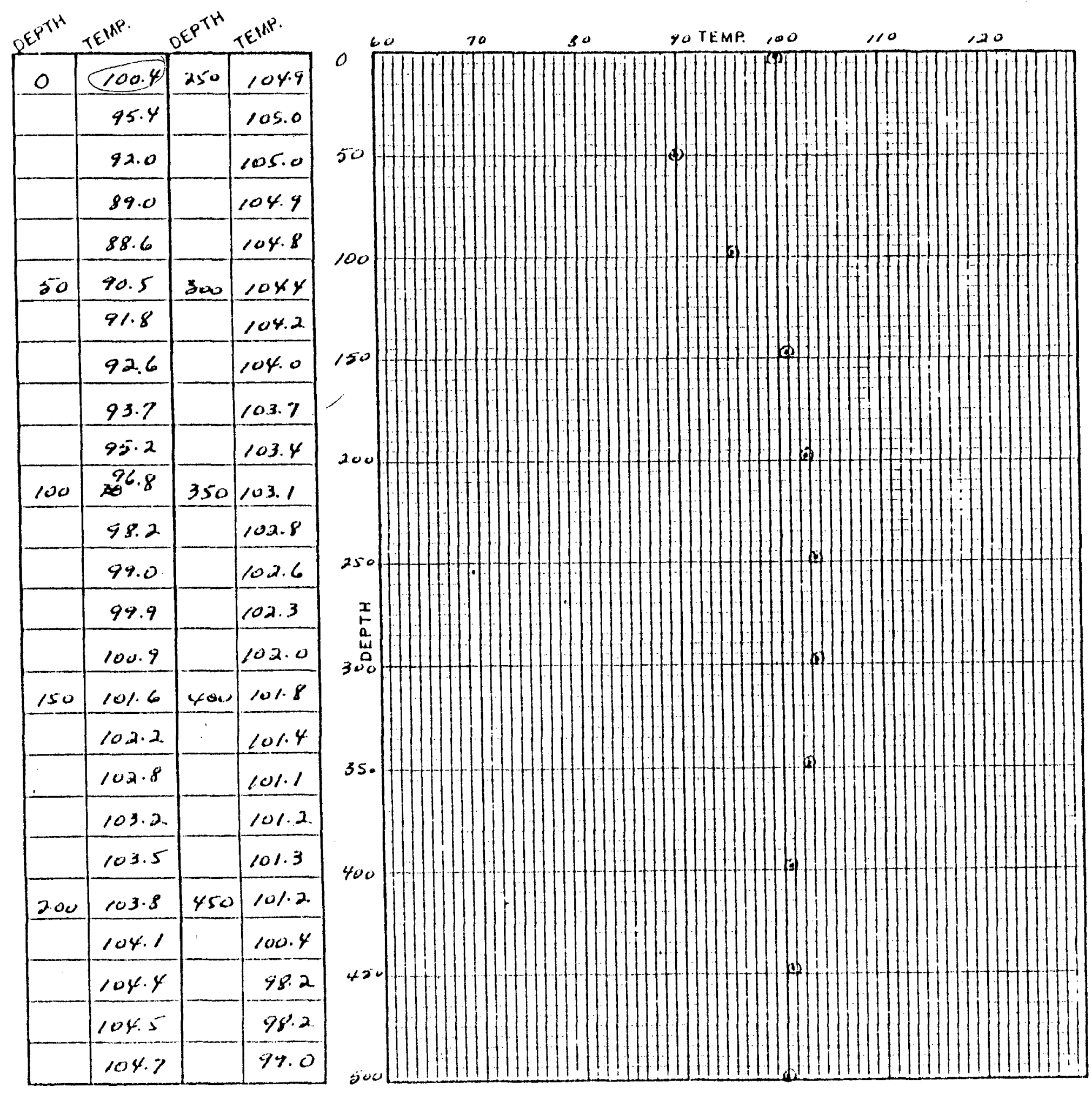

Salis w HOLE \# 1000.2.

$$
B A C-1
$$

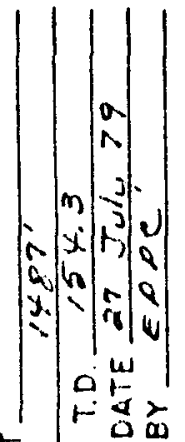

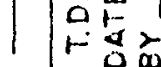

点造战

a

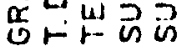

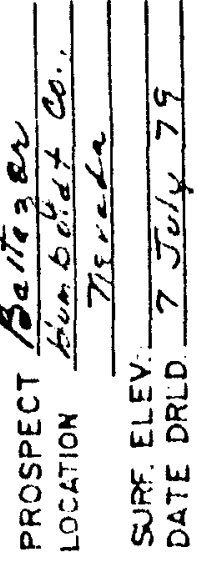

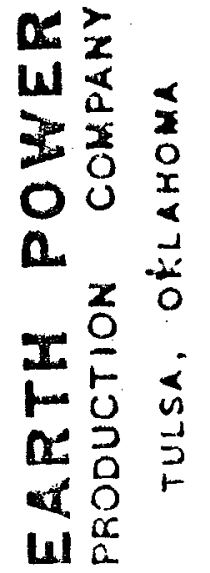




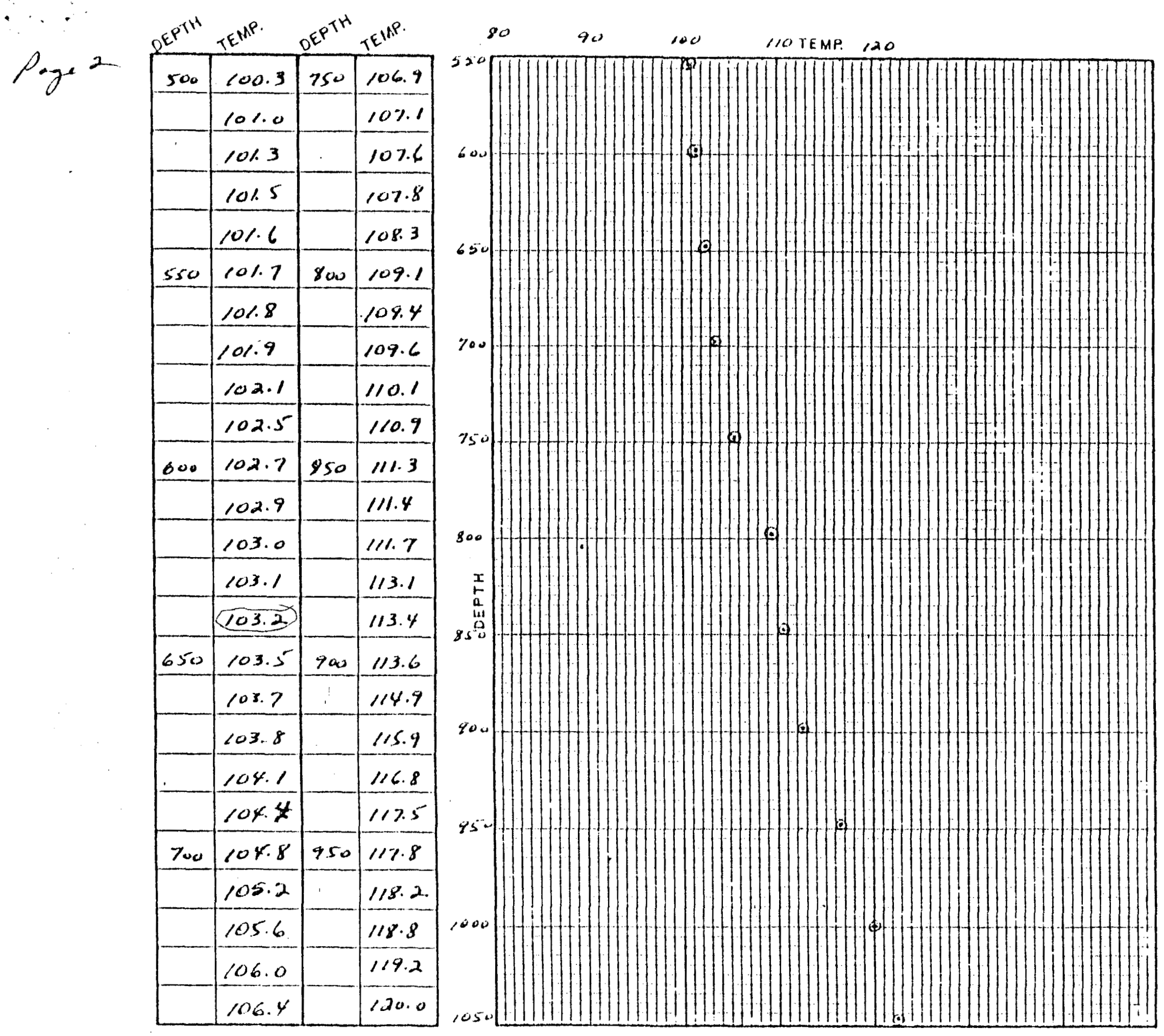

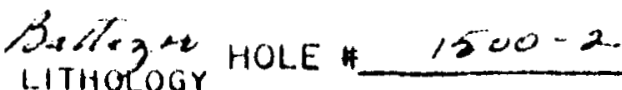

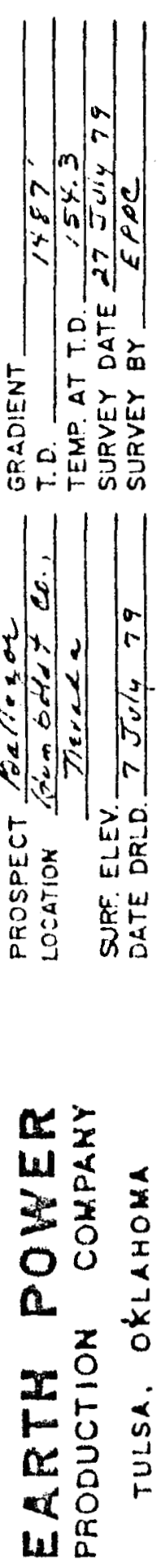



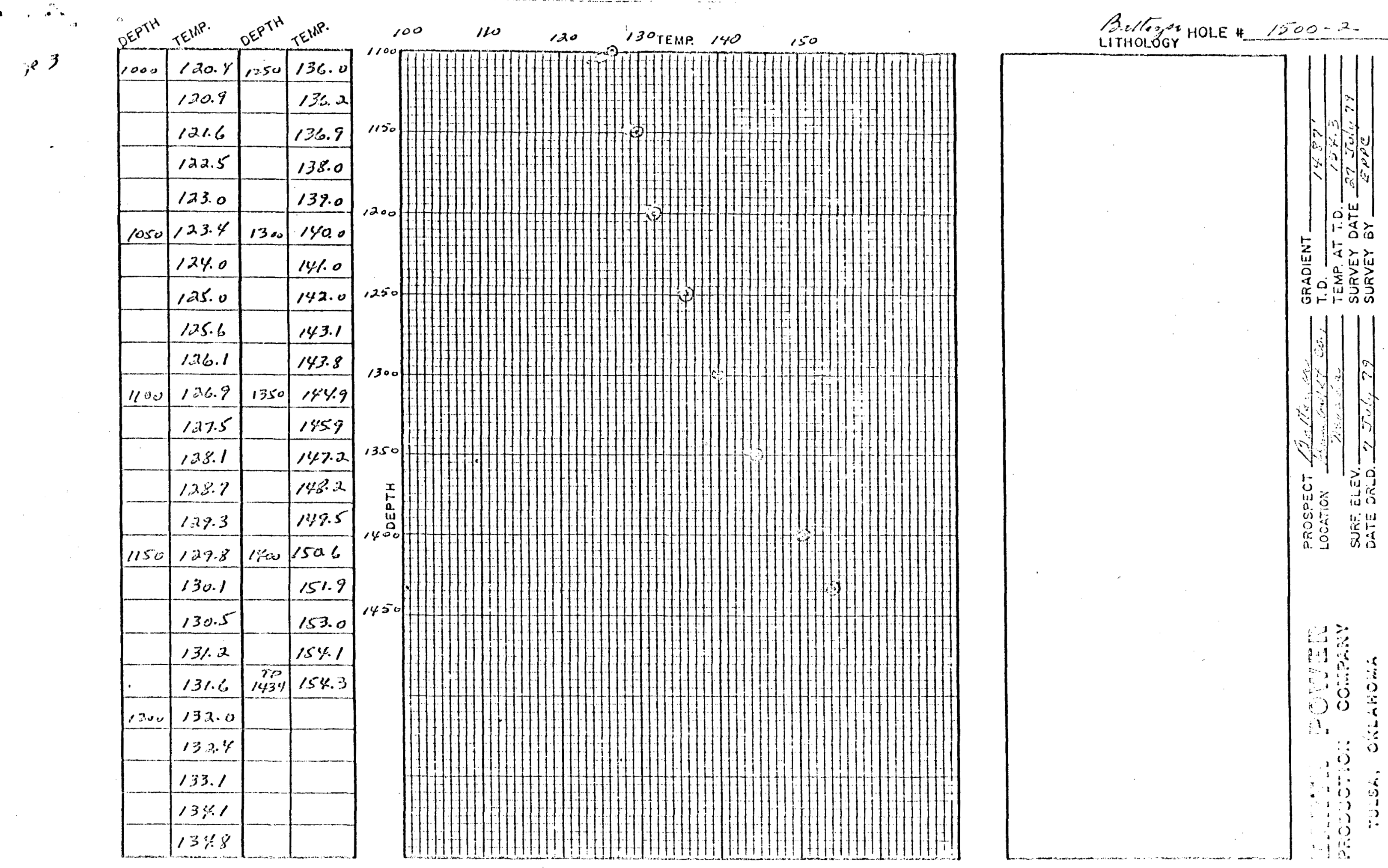


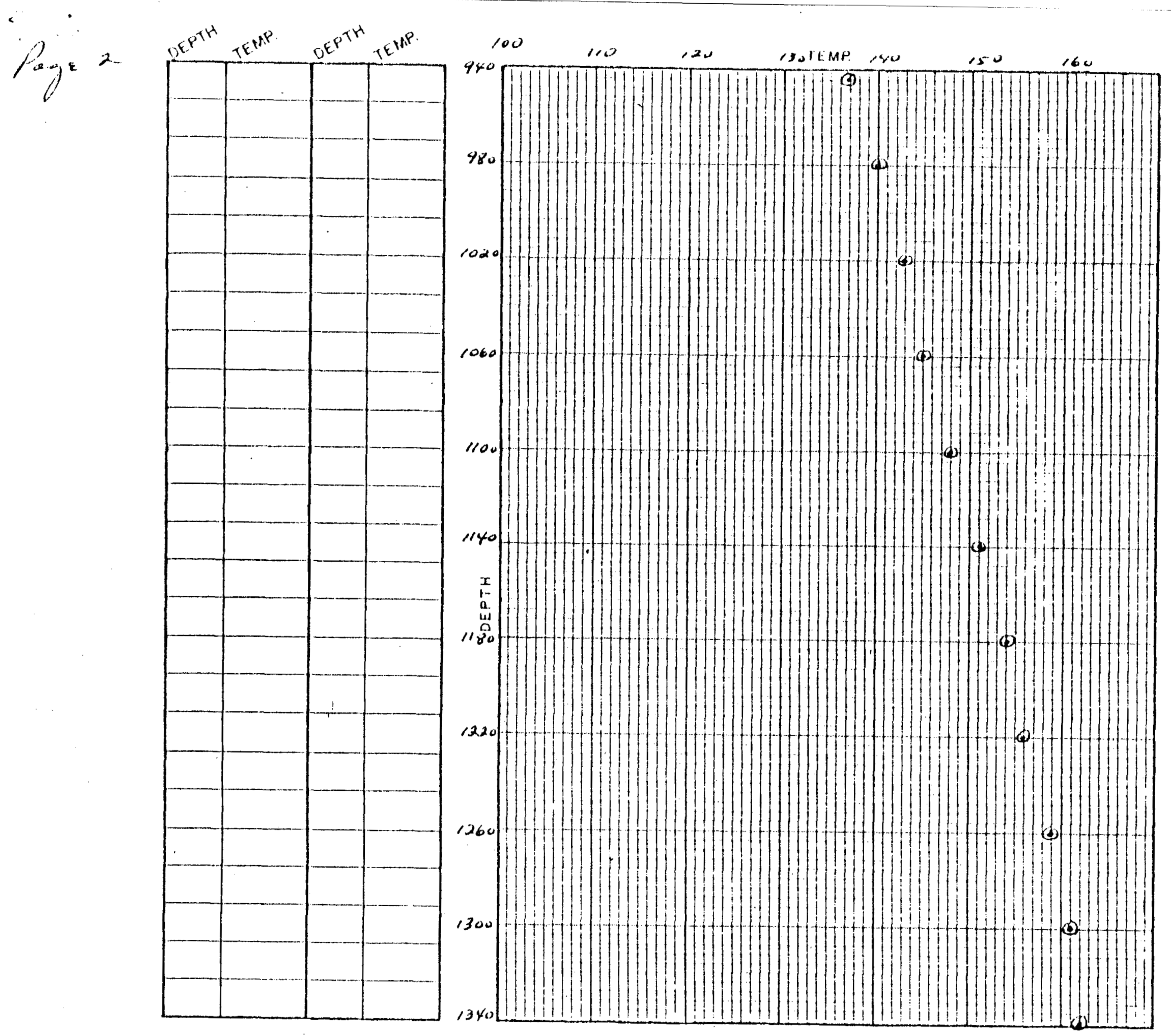

LITHOLOG HOLE H 1500 a

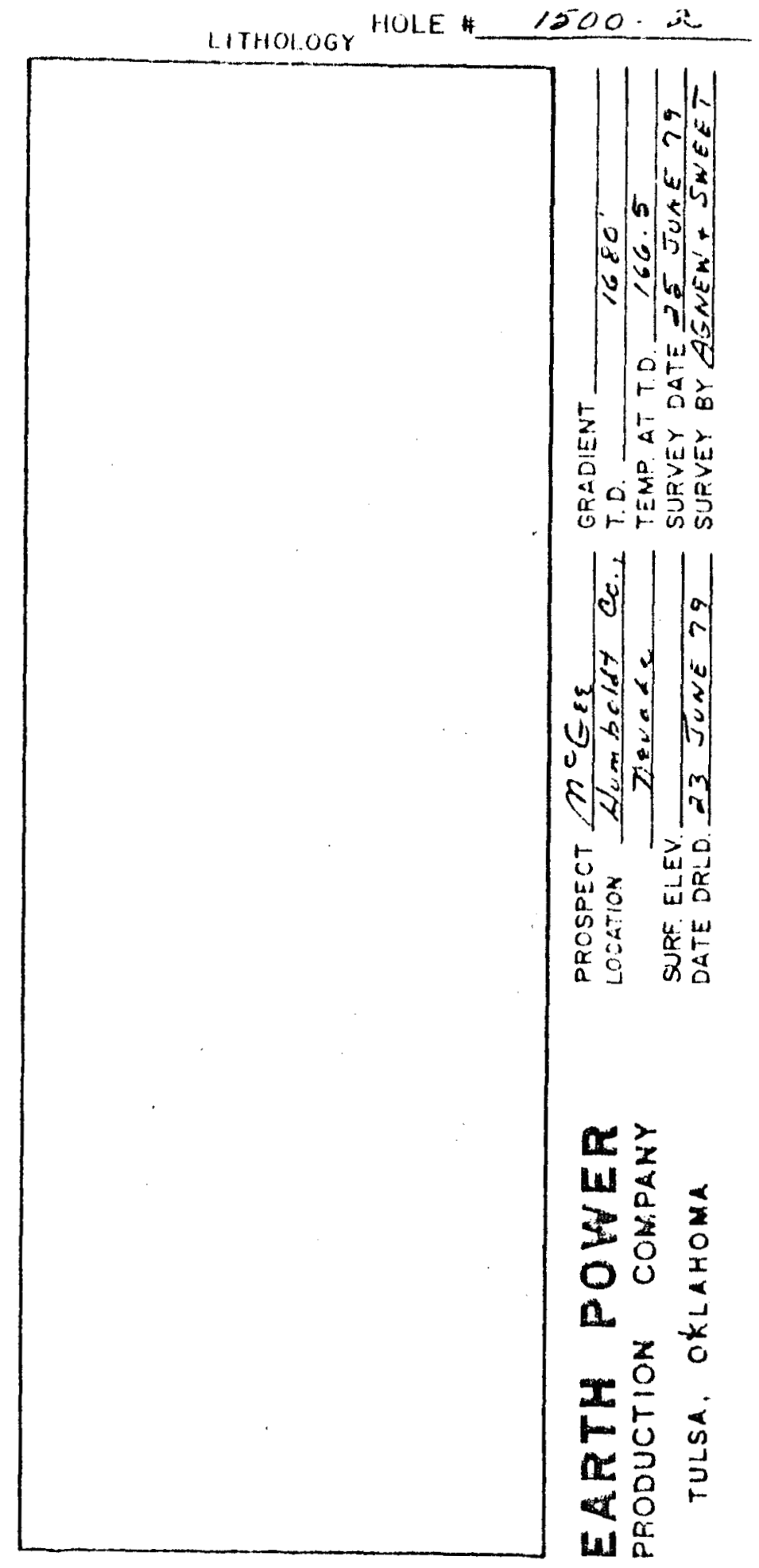



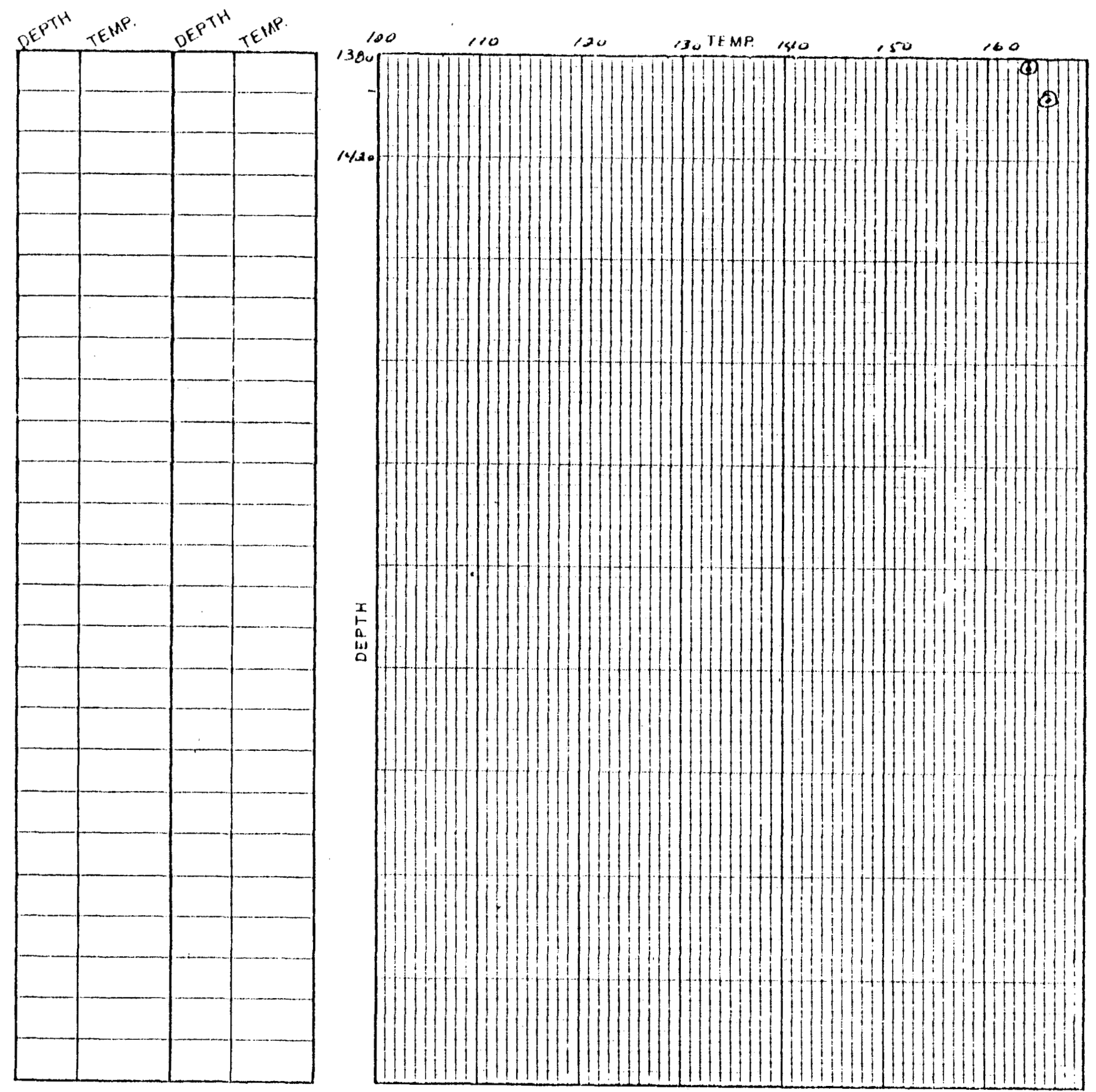

1.1THOLOGY HOLE \#_1500- $x$

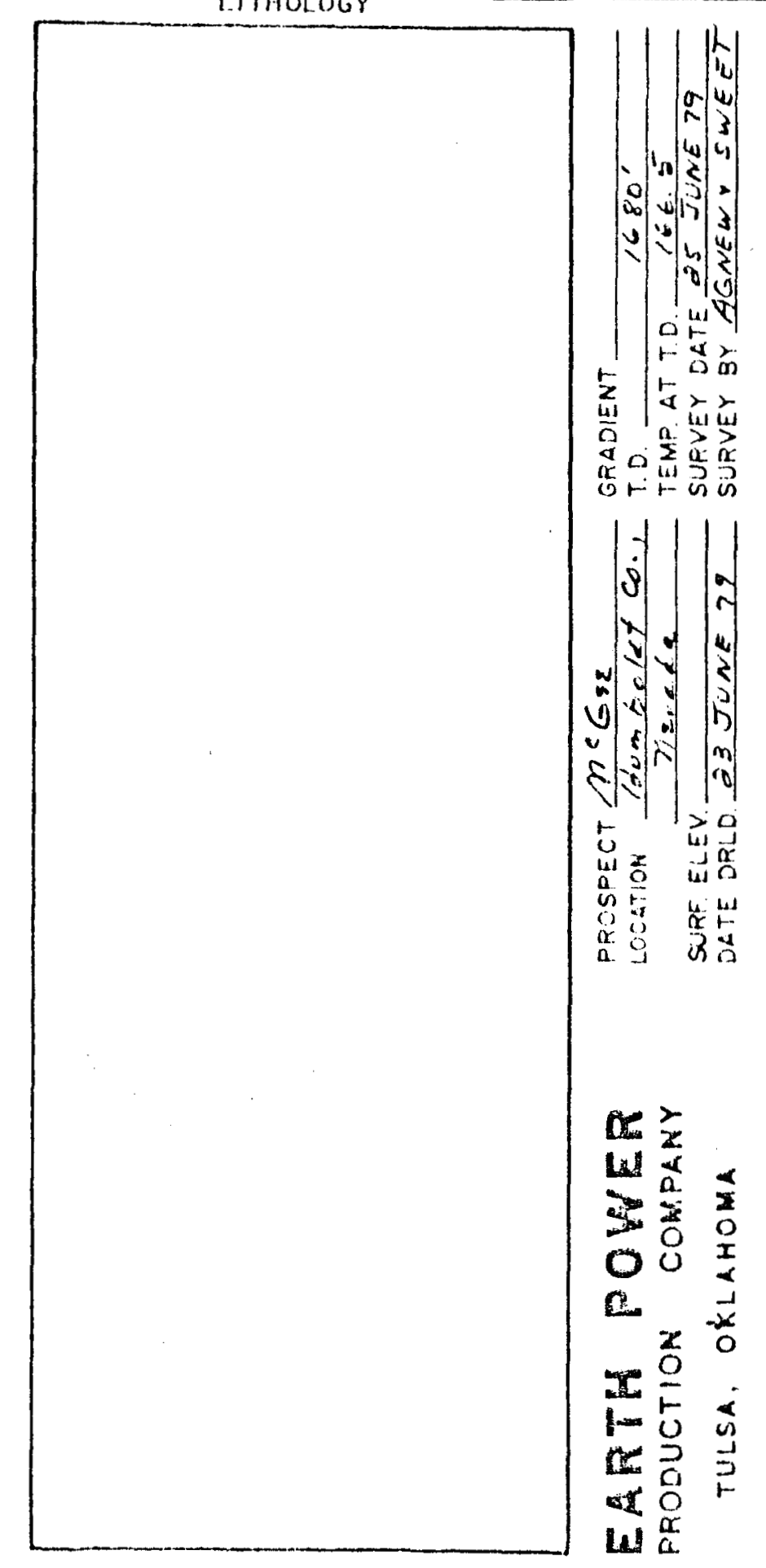


$P^{\prime} g^{2}$

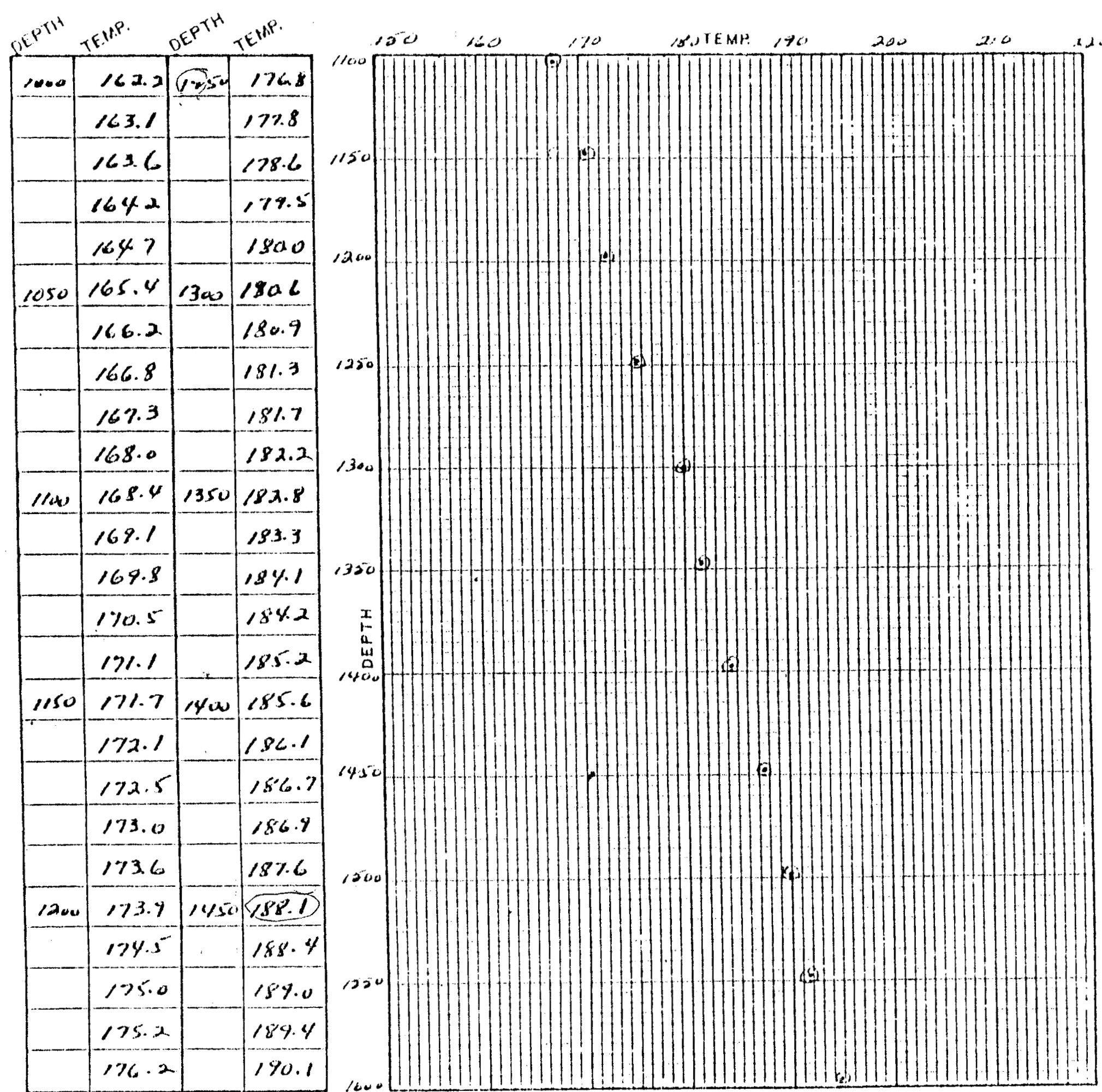

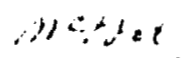

HOLE H 12 .

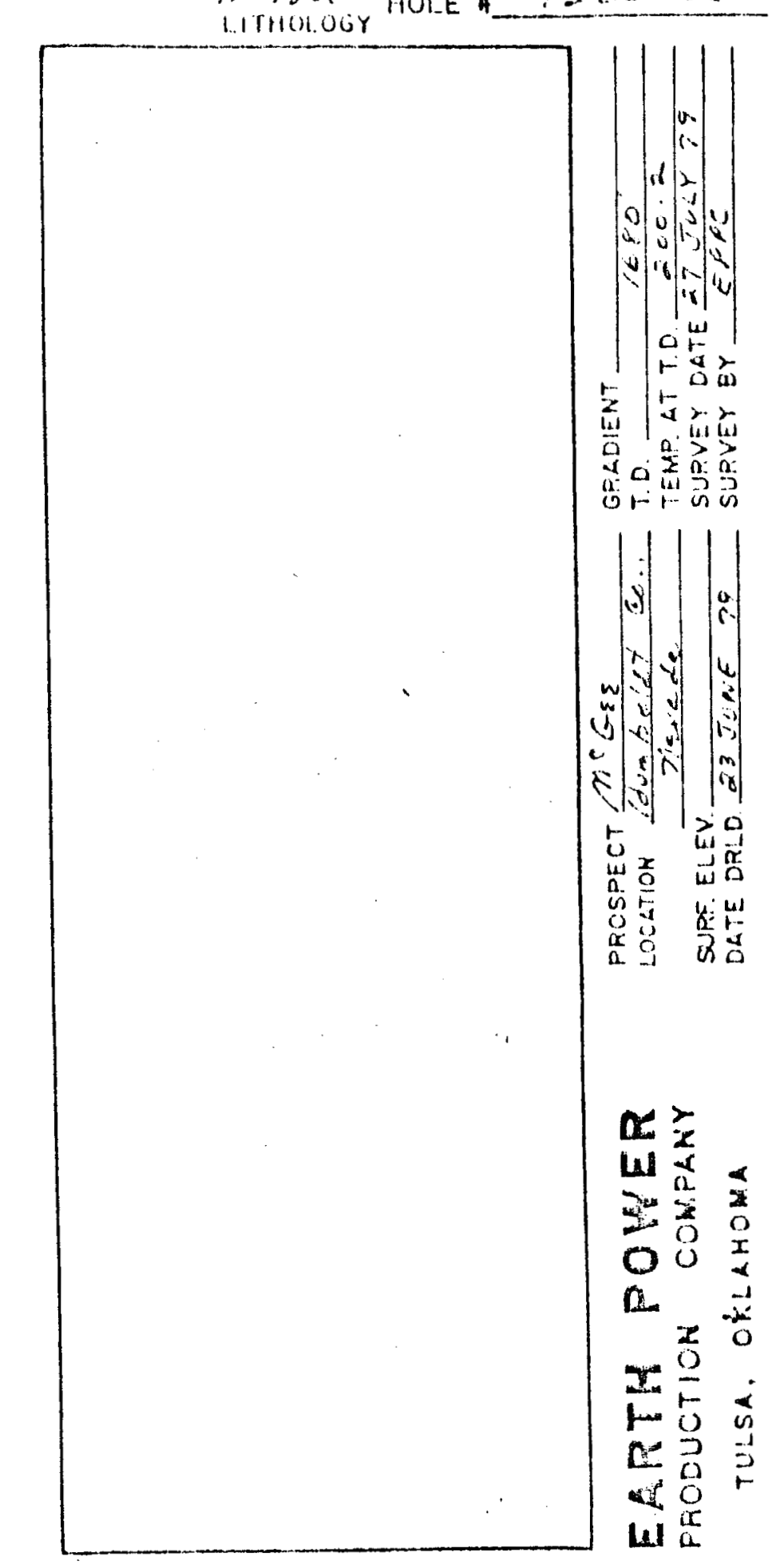




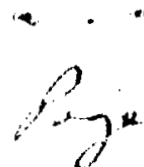
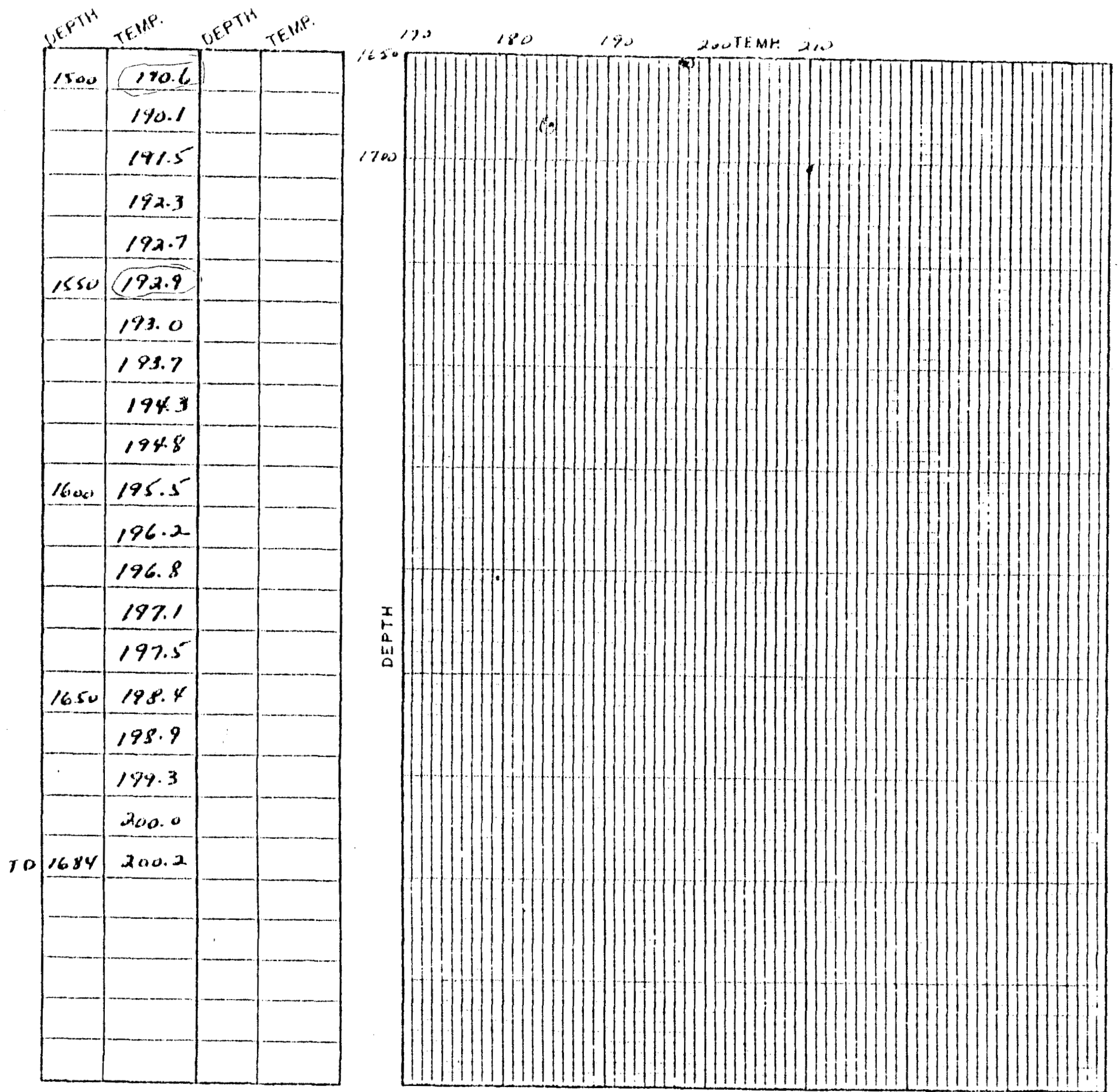

AStrer HULE

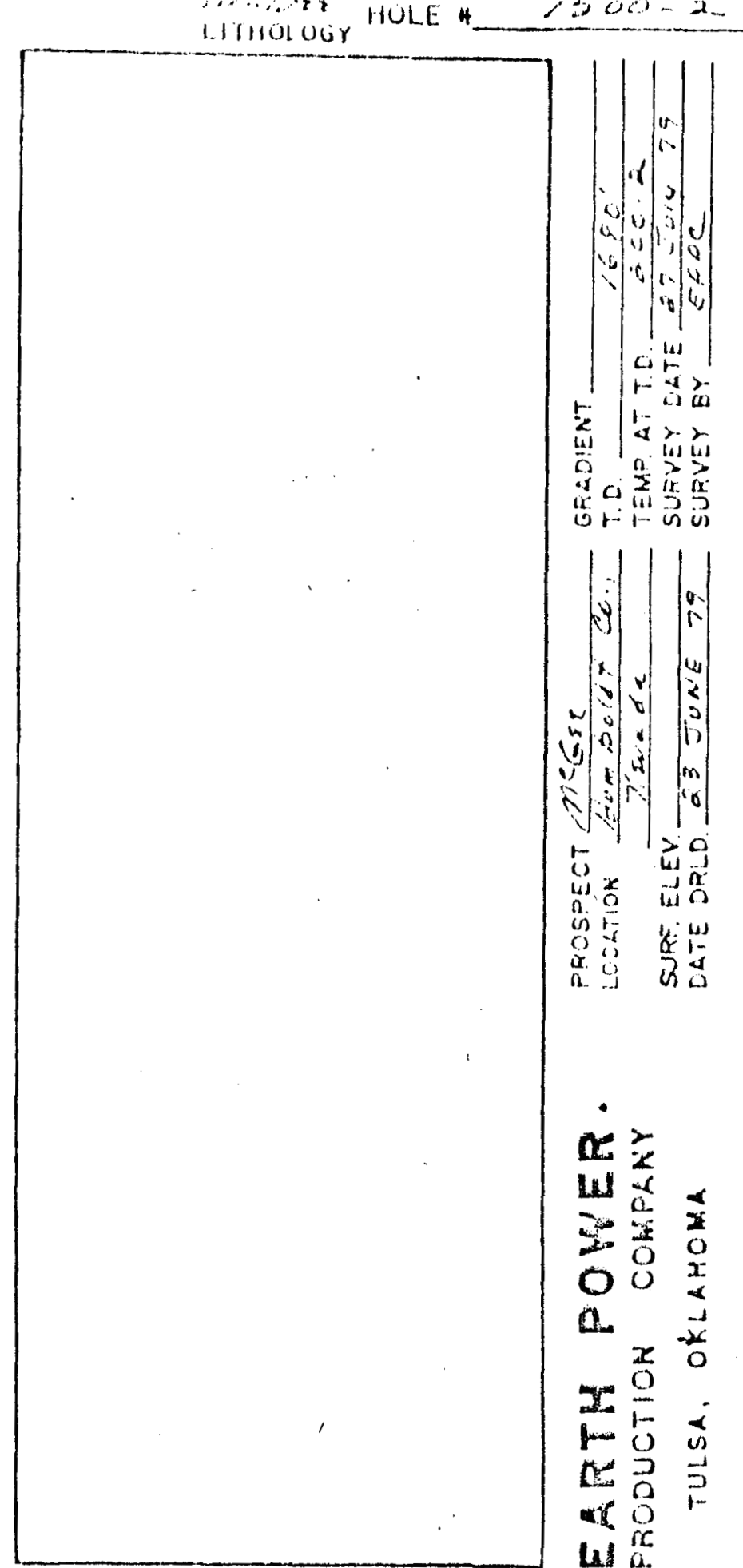

